\title{
Celebrity Studies
}

\section{Introduction: Navigating with the Blackstar: the mediality of David Bowie}

\section{Ana Cristina Mendes \& Lisa Perrott}

To cite this article: Ana Cristina Mendes \& Lisa Perrott (2019) Introduction: Navigating with the Blackstar: the mediality of David Bowie, Celebrity Studies, 10:1, 4-13

To link to this article: https://doi.org/10.1080/19392397.2018.1559959

曲 Published online: 11 Mar 2019.

Submit your article to this journal ๘

View Crossmark data $[\pi$ 


\section{Introduction: Navigating with the Blackstar: the mediality of David Bowie}

\section{Ana Cristina Mendes (10 a and Lisa Perrott (10 ${ }^{\mathrm{b}}$}

aSchool of Arts and Humanities, University of Lisbon, Portugal; bFaculty of Arts and Social Sciences, University of Waikato, Hamilton, New Zealand

KEYWORDS David Bowie; Celebrity Studies; Mediation; Stardom; Transmedia

Less than a week after the physical death of David Jones in New York, on 10 January 2016, a new David Bowie mural appeared on a wall in Turnpike Lane, North London. Stencilled by the street artist Pegasus, Bowie resurfaces in his 1970s Aladdin Sane persona, his upper body encircled by five-pointed stars. Having a closer look at the surface of this wall at the time when the artwork was made, we can clearly see how it has already had a rich, complex story - like all walls in a city do, and how the earlier texts on that wall work as a haunting hypotext, one that the later texts transform. Pegasus' tribute to Bowie was stencilled next to other pieces such as a Banksy trademark rat and Mobstr's Darling look, it's a Banksy! (2014), and palimpsestually imprinted onto earlier artworks, such as the Banksy 2012 mural Slave Labour (controversially removed and sold at a private auction for $£ 750,000$ in 2013) and others which had been painted over (including Nun Nicer's art of 'whimsical beautification', erased as pieces of - technically illegal - vandalism).

Following the announcement of the death of David Jones, many other tributes were rendered. Many took to social media - Facebook was the privileged venue for impromptu homages and compulsive video sharing via YouTube; a new record for the most video views in 24 hours was broken on Vevo. In particular, Bowie's self-referential adieu 'Lazarus', a single from his last, almost posthumous album Blackstar, released just two days before his death, struck a chord with listeners.

Despite the death of David Jones, David Bowie continues to shine with a distinctive luminosity and navigational function. He shines in absence and in repetition in various venues, as on a wall in Turnpike Lane (Figure 1 and 2). Our approach to this special issue of Celebrity Studies is framed by the idea that a social, cultural, ideological and semiotic understanding of stardom is entirely fitting for an examination of David Bowie and his legacy. Building on previous research on Bowie's star personae (Stevenson 2006, Cinque and Redmond 2014, Cinque et al. 2015), this framework can be further inflected by considering the cosmological significance of stars in relation to Bowie. For instance, stars provide constellations of perpetual guiding points which enable enlightened communities to navigate pathways. Stars also have a spectral dimension, since they are luminous, but not always visible. Stars might seem static and omnipresent, but they are constantly transforming, changing appearance, ageing, living and dying. As Bowie has so aptly emphasised in his lyrics and interviews, there are many different types of 


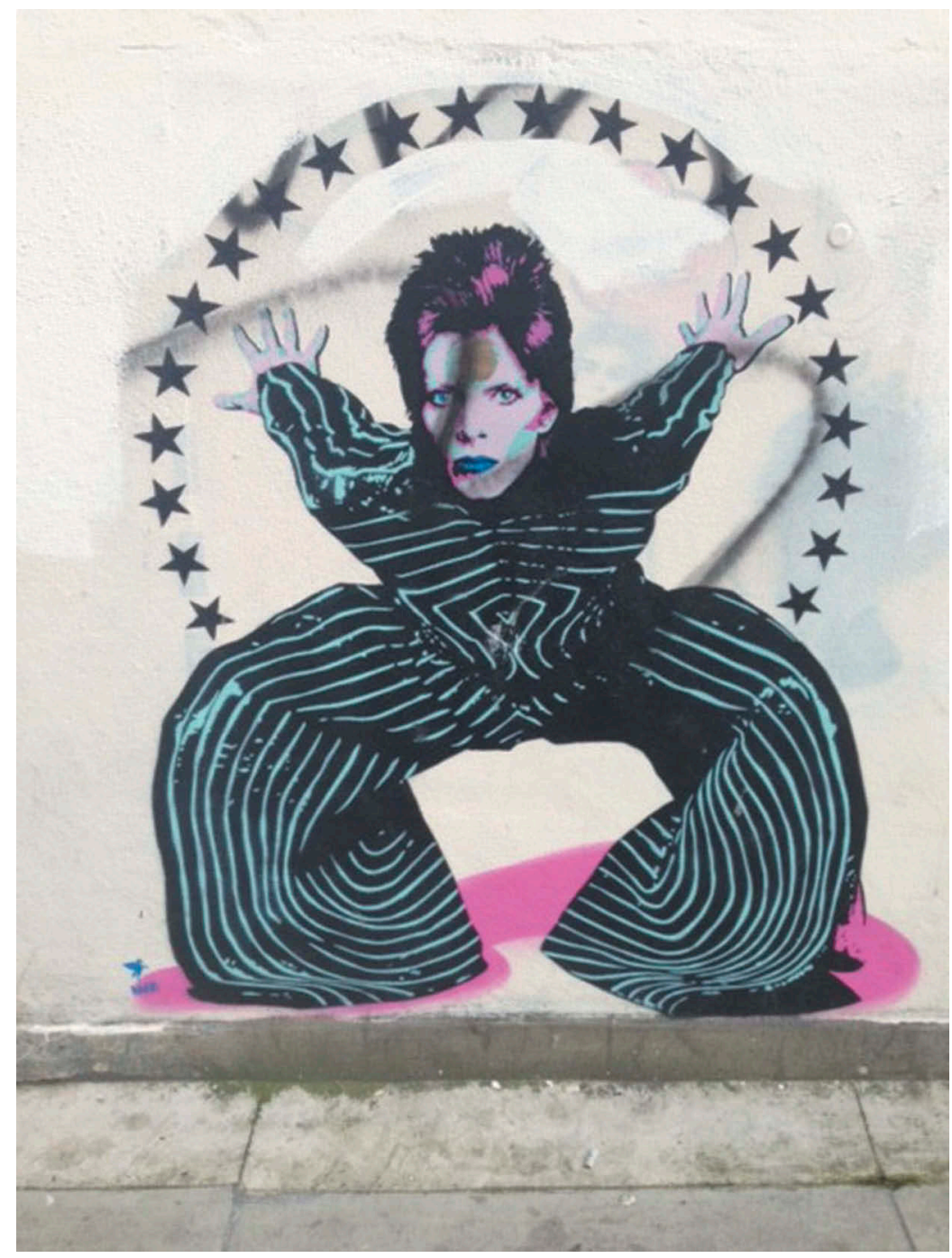

Figure 1. Pegasus' star-surrounded Bowie mural in Turnpike Lane, North London. April 2016. @ Ana Cristina Mendes.

stars (including his contentious statement that 'Adolf Hitler was the first pop star'), and it was important that he set the record straight about which type of star he is: '... not a film star... not a pop star... not a marvel star... not a gang-star... I'm a star's star... I'm a black star'. ${ }^{1}$

This special issue grew out of the 2016 David Bowie Interart | text | media Conference held at the School of Arts and Humanities, University of Lisbon. The conference called for an examination of Bowie's oeuvre and its global legacies across the many media platforms and art spheres his creative output - from Starman to Blackstar and beyond intersects with, including music, lyrics, video, performing arts, literature, theatre, film, television, the internet, exhibitions, installations, design and fashion. In short, our aim was to address the interart, intertextual and intermedial dimensions of Bowie's sonic and 


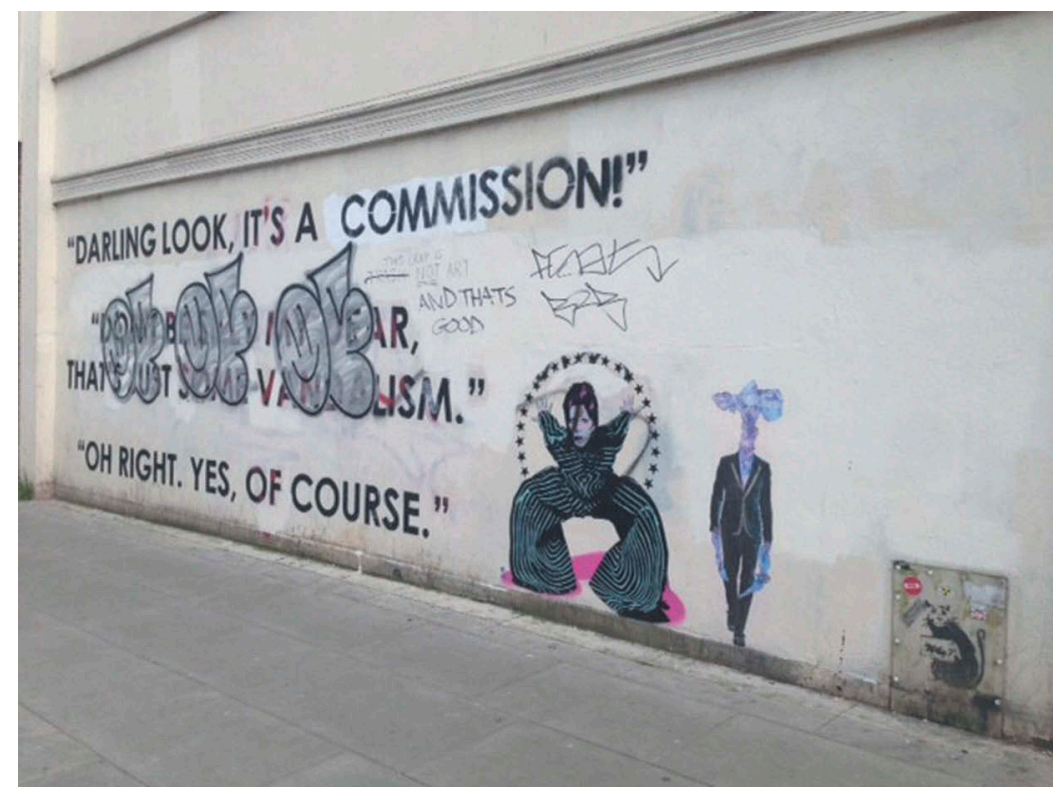

Figure 2. After three months, the wall of Pegasus' Bowie mural has been populated by other works. April 2016. () Ana Cristina Mendes.

visual legacies. Spanning more than five decades, Bowie's career as a singer, songwriter, musician and record producer is invested with a star's luminosity that shines well beyond the remit of pop music. From the early days of his career, the presence of interart and intermedia forms is persistent - in the late 1960s, then an aspirant pop singer studying dramatic arts under performer Lindsay Kemp, Bowie was experimenting with mime, kabuki and commedia dell'arte. This clearly impacted the creation of his artistic personae, artfully appropriating avant-garde ideas and bringing them to the realm of popular culture. Many of his songs draw on interart, intermedial and intertextual forms, e.g. the title of 'Space Oddity' (1969), his breakthrough single, is a pun on Stanley Kubrick's 2001: A Space Odyssey (1968); 'The Drowned Girl' (1982) is a version of Bertolt Brecht's poem inspired by the death of the Polish Marxist theorist Rosa Luxemburg, originally titled 'On the Girl Beaten to Death', set to music by Kurt Weill in 1928 as 'Ballad of the Drowned Girl' for Berliner Requiem. His lyrics reference works from Sigmund Freud's Interpretations of Dreams (1899) to George Orwell's 1984 (1949). Besides his music and acting careers stricto sensu, he was actively involved in the visual arts - he studied art and design, together with layout and typesetting, collected German Expressionist and British contemporary paintings and was a painter himself, sat on the board of the art journal Modern Painters (for which he also contributed art criticism), designed wallpaper, and collaborated with visual artist, entrepreneur and art collector Damien Hirst, and multimedia and installation artist Tony Oursler.

Our approach to the issue starts from the assumption that the star David Bowie is a medium in transit, undergoing constant movement and change. Although signifying discontinuity, Bowie developed many threads of continuity across media, platforms, space and time. Within the context of celebrity studies, the concept of stardom provides 
an appropriate frame for an examination of Bowie's transmedial activity - especially given his ongoing iconic signification within the celestial realm. While Bowie has traversed many mediums, he has also been described as a medium, which is consistent with the way he has described himself. For instance, Kathryn Johnson argues that 'Bowie's creation of sophisticated and eminently saleable work can be more convincingly and coherently interpreted as part of the process of becoming a "medium'" (2015, p. 15); Mehdi Derfoufi posits Bowie as 'a star of the transmedia era' (2015, p. 160), qualifying the statement by adding a personal note: 'I discovered Bowie when I saw Absolute Beginners (Julian Temple, 1986) at the movies (in fact, I had already "seen" him on soda bottle caps in Morocco when I was six or seven but that doesn't count, even if I was hugely impressed by his extraterrestrial-like face)' (Derfoufi 2015, p. 175).

For this special issue, we aimed to connect these ideas about the agency and crossing of media to the notion of stardom, as it has been developed from its initial emphasis on film stars to its broader application, due in part to the increasing permeability of the borders between media platforms (Dyer 1979 and 1986, Gledhill 1991, Rojek 2001, Barker 2003, Ndalianis and Henry 2002, Holmes and Redmond 2006, Nayar 2009).

Given the range of perspectives already published about the mediation and stardom of David Bowie, we wanted our contributors to draw upon these, whilst also probing uncharted territory - to tap into diverse theoretical perspectives and try out unexpected approaches. Considering the way a laboratory petri dish functions in the biological sciences, we hoped that our editorial approach to this special issue would provide the 'culture medium' (in the metaphorical sense developed by Toija Cinque in this issue), from which ideas would grow and link to form constellations - both within, and across the articles. We wanted our contributors to test the efficacy of concepts and methods, and to try out their usefulness as tools for examining the mediating processes that occur in the spaces between celebrity, stardom, fandom, media and culture. Representing a broad spectrum of disciplinary areas, identities and international locations, our authors were selected on the basis of their expertise along with the proximity and originality of their proposed approach to the topic of our special issue. While not all our contributing authors have an extensive knowledge base in celebrity studies, we believe that each brings fresh insight into this developing field, whether that be specialist knowledge of fashion, performance, literature, audiovisual media, visual analysis, popular music, audience and reception studies, cultural studies or media studies.

We encouraged the authors to consider the conceptual significance of the terms 'mediation' and 'navigation', from many different perspectives toward the stardom of David Bowie. The results have been insightful and theoretically productive. While there is some common ground in the way the term mediation has been conceived, each author has also provided their own fresh take on its application to Bowie. Figuring prominently across several of the articles is Marshall McLuhan's approach to mediality, particularly his conceit 'the medium is the message' (1964). His theorisation of the term 'constellation', as discussed by Norm Friesen (2013), usefully frames this special issue, providing an appropriate celestial metaphor for considering the kaleidoscopic aspect of Bowie's approach to stardom, as well as our author's different approaches to this topic. Highlighting the originality of each of the articles in this special issue, McLuhan's metaphorical kaleidoscope brings into view newly configured and unexpected constellations of Bowie's engagement with mediality and stardom. In the articles that follow, 
Bowie is examined; as a medium, becoming a medium, transiting across media platforms, inciting processes of remediation, and mediating his audience's engagement with time, space, celebrity, stardom, spectrality and death. Due to the innovative approach taken by the contributing authors, these powerful ways of conceiving mediality have been developed, stretched and applied in surprising ways, as has the term navigation.

While some contributors focus on the navigational functions of stars in a constellational or cosmological sense, others have discussed the navigational function that Bowie offers his fans in terms of philosophical and cultural guidance, or the capacity of a star to illuminate pathways leading toward the formation and negotiation of identity. Some authors demonstrate that Bowie's approach to stardom could lead us to consider that the term navigation doesn't need to imply a one-way process of illumination or guidance. This term also has significance for the ways in which Bowie himself utilised stars, performers, artists, philosophers, video directors, and his fans all as points of navigation that would enable himself to change direction, reform personae, experiment with new creative strategies, and eventually to enlighten his pathway toward exiting the mortal world in a way that would assure his continuation as an influential spectral figure. These different approaches to mediation, navigation and stardom have informed the way in which we have organised the articles in this special issue.

Drawing on the German Romantic concepts of constellation and elective affinity, Susan Ingram considers what stardom means in the context of Berlin, as she charts the importance of Berlin for Bowie and the importance of Bowie for Berlin. Seeking to elucidate the stylistic implications of a form of stardom manifesting a dark aesthetic, Ingram draws together Bowie's Berlin experiences with the countercultural personalities Christiane Felsherinow and Hedi Slimane. In particular, her arguments travel in the direction of a Benjaminian constellation with Berlin as the 'Knotenpunkt', or node, joining Felsherinow and Slimane with Bowie. The matrix of Bowie and these countercultural personalities is examined in relation to particular aesthetic associations with Berlin, as mediated via cinematography, music video and fashion.

Also concerned with fashion as a medium, Mairi MacKenzie examines the influence of an outfit worn by Bowie in The Man Who Fell to Earth, and again upon the cover of his 1977 album, Low. While this distinctive duffel-coat may be for many fans indelibly associated with these iconic visual and sonic records of Bowie, it is considered here as a medium that has influenced the evolution of the earliest football casuals of Liverpool F.C., in the period from 1976-79. MacKenzie uses this outfit as a site for consideration of fandom and emulation in popular music, demonstrating the transmedial narrative flow between music and fashion, as well as the transference and creation of fashion cultures. This study of the influence of a banal outfit upon a specific culture contributes fascinating insights into the materiality of transmedial cultural transit and influence of imagery via the media of fashion. Concurrently, by engaging with a particular subcultural response to the iconic image of a star figure, MacKenzie also shows how Bowie's stardom provided points of stylistic navigation, which were followed by cultures and communities that would not usually be considered within the frame of Bowie fandom.

Bowie's navigational function for a fan community rarely under the scholarly microscope is also examined by Toija Cinque. Focusing on Bowie fans who also happen to 
be academic scholars, Cinque develops existing notions of aca-fandom toward a new perception of aca-fan conferences built in and around star and celebrity figures. In particular, Cinque draws upon the focus groups on David Bowie organised in the context of two aca-fan conferences (the 2016 David Bowie Interart | text | media Conference in Lisbon and the Celebrity Studies Conference 2016 in Amsterdam) as primary material to critically consider this emerging strand of academia that circumnavigates studies of stardom. Borrowing the term 'culture medium' from the biological sciences, and examining aca-fan responses from focus group participants, Cinque considers how Bowie's work acts metaphorically as a rich medium for aca-fans' emotional growth and subsequent active agency. While demonstrating how this emerging field of stardom and fan-studies offers a way to re-evaluate star and aca-fan relations, Cinque critically considers the ways that David Bowie has become an emotive subject within a media-rich world. As a means of delving into the types of emotional responses that are stirred by fandom, Cinque draws upon auto-ethnographic methods, which allowed the fans in her study to 'story' their responses to David Bowie.

Also utilising auto-ethnography as a methodological device for exploring Bowie fandom, Amedeo D'Adamo considers the navigational function of Bowie in relation to existential processes that he identifies as accompanying a fan's imaginative engagement with identity, community and belonging. D'Adamo analyses the music and video for 'Blackstar', which he compares to other songs and videos including John Lennon's 'Strawberry Fields Forever'. Drawing on philosophical perspectives ranging from Bernard Williams' (1993) conceptualisation of social necessity to Benedict Anderson's (1991) view of the nation as an 'imagined community', D'Adamo explains how a fan may be inspired by Bowie to navigate pathways of necessity and possibility. Considering these pathways in relation to hegemony and the agency of a fan, D'Adamo argues for a new approach toward theorising fans as agents of their own possibility. In doing so, he provokes readers to consider Bowie's navigational function as a medium that models to his fans how one might re-imagine possibilities of place and identity.

Taking yet another approach toward mediality, Alison Blair shows the relationship and mutual influence between David Bowie and Marc Bolan. Blair hence focuses on the dynamic intermedial space between two stars who looked to each other for navigational and cosmological inspiration. Both media texts in their own right, Bowie and Bolan's production of media texts also provided navigational guidance for their fans. By examining the mutual intermediality between Bowie and Bolan, departing from studies that focus on the 'rivalry' between these 'media stars', Blair shows how they drew upon each other's carnivalesque personae, visual aesthetic, thematics and use of narrative structure. Using theories of the carnivalesque, dialogism and intertextuality, Blair argues that the intermediality between Bowie and Bolan extended to a recognition, particularly within Bowie's work, of each other's media stardom. While this study focuses sharply on the intermedial space between two stars, Blair places this object of study within a broader cultural and political frame, thus illuminating the way in which both stars served as navigators for their fans; their glam personae providing counter-hegemonic alternatives to norms of identity within the context of 1970s Britain.

Also considering Bowie's role in illuminating alternative pathways for his fans, Elizabeth McCarthy focuses on his propensity for fakery and telling lies via the medium of celebrity interviews. While the interviews examined in this article provide a fascinating perspective on 
Bowie's life and art, McCarthy's interpretation of them as a narrative-of-self as well as a form of artist's statement, reveals a slippery process of 'narrative identity' in which the 'self' is both affirmed and rejected. Viewing this 'self' as both interpreter and interpreted, McCarthy demonstrates how Bowie's stardom is constantly under revision by both Bowie himself and by those who mediate and interpret it. By exploring the productive possibilities of the celebrity interview as an indeterminate in-between state, in particular, of the celebrity interview as a stage for Bowie's mediation, and by considering Bowie's stardom as a boundless collaborative project (in which his fans participate as collaborators), McCarthy discusses the significance of Bowie's fascination with the 'grey space' in the middle of an artist, their works, and audience interpretations. By illuminating the collaborative role of the Bowie fan within this grey space, McCarthy also demonstrates how 'navigating with the Blackstar' is not a one-way process, since Bowie also used his fans as points of navigation.

The productive potential of this 'grey space' for Bowie and his collaborators is also a key theoretical insight developed by Dene October, who extends upon existing conceptions of Bowie's mediality by examining the transmedial transit and seriality of the Bowie-Newton matrix, and what this means for media as collective and personal memories. Drawing upon theories such as transmediality (Jenkins 2006), performativity (Derrida 1988, Butler 1990), celebrity (Marshall 2014), media communications (McLuhan 1951), actor-network theory (Latour 1993) and seriality (Buonanno 2008, Kelleter 2014), October frames his examination of Bowie and Thomas Jerome Newton as serial figures transiting across different media platforms and texts. These include the theatrical production Lazarus (2015), based on the science fiction novel The Man Who Fell to Earth (1963) by Walter Tevis (whose 1976 film version directed by Nicolas Roeg starred Bowie), and Tom Hingston's music video for No Plan (2017).

Supported by McLuhan's claim that 'the medium is the message' (1964) as well as Bowie's description of himself as a medium, October considers Bowie's agency as medium for 'his' characters. In this respect, October utilises his abstract model of the Bowie-Newton matrix as a conceptual tool, enabling him to speculate on what he observes as 'the dispersed agencies - of author/actor, character, and studious viewer behind Newton's resurrection'. Providing an enduring visual metaphor for this abstract idea, October concludes by emphasising the agency suggested by viewers gazing into the Newton Electrical shop window, as depicted in Hingston's video for No Plan.

Picking up from where October left off, the evocative visual and sonic power of the video for No Plan sets the scene for Lisa Perrott's examination of the hauntological mediation of David Bowie. Extending upon existing theories of hauntology (Derrida 1994, Fisher 2014) and remediation (Bolter and Grusin 2000), Perrott applies these flexible concepts to her analysis of a selection of Bowie's audio and visual media forms, thus demonstrating their combined usefulness as tools for transmedial analysis. Here, mediation is considered in a spectral sense, where a 'medium' may function in multiple ways to bring about a sense of temporal disjuncture, thus triggering new perceptions of the past and the future. As suggested by the anthropomorphic television screens in No Plan, just as metaphorical spiritual mediums propose to enable communication with the dead, this notion can be applied to other types of mediums. Iconic mediums, media stars, material and cultural mediums can call up memories of prior media forms, stars or iconic figures from the past, just as they can also conjure 
associated material traces, sounds, timbres, visual images, gestures and bodily sensations. In her examination of songs, cover art and music videos selected from significant moments in Bowie's oeuvre, Perrott shows how Bowie stretched the possibilities of hauntology as a conceptual tool and an artistic strategy. Further, she claims that through his extensive engagement with 'future nostalgia', spectrality and death, he prepared the cultural bed for audience members and cultural participants to engage with hauntological media.

Likewise focusing on Bowie's preparation for his assured continuance after death, Gareth Schott considers how Bowie served as an agent of his prospective memory by addressing his death directly in his final album Blackstar, and in its associated audiovisual outputs. Schott examines how the release of these media forms had the effect of orchestrating a quite different public response to that of other celebrity deaths. He argues that 'public fascination with past symbolic embodiments of Bowie's celebrity in the wake of his death were partially redirected by the artist himself with the release of Blackstar'. While the objects of examination are Bowie and his musical and audiovisual outputs, Schott builds upon Edwin Shneidman's (1973) concept of 'post-self' to paint a richly nuanced picture of the capacity of celebrity figures to mediate and reconfigure public representations of death. As such, this article provides a frame by which to contemplate the many diverging ways in which death has been mediated, and to consider how Bowie's production of an iconic life after death assures his continuing function as a navigator for consecutive generations of potential fans, and for anyone who thinks about mortality.

Given the sense of kaleidoscopic transformation potentiated by these different approaches to the stardom and mediation of David Bowie, it seems entirely fitting to introduce this special issue with a quote by one of Bowie's philosophical navigators Marshall McLuhan (taken from his introduction to The Gutenberg Galaxy).

'...the galaxy or constellation of events upon which the present study concentrates is itself a mosaic of perpetually interacting forms that have undergone kaleidoscopic transformation' (McLuhan 1962).

\section{Note}

1. On the left-hand side of Pegasus' Bowie artwork, Mobstr's block lettering ' - Darling, look, It's a commission. - Don't be silly my dear. That's just some vandalism. - Oh right. Yes, of course', stenciled in 2014, is a response to the 'theft' of the Banksy mural. This mural, on the side of a Poundland store, depicted a child sewing a bunting of Union Jacks (presumably Diamond Jubilee and London Olympics memorabilia). Hence the play with the words 'commission' and 'vandalism'. Pegasus' Bowie tribute was stenciled in the space occupied by this Banksy high-profile mural. See Hansen and Danny (2015, p. 898) for an account of the 'emergence of a lively local intertextual visual dialogue' in this particular public space over a period of 18 months following the removal of Banksy's piece (February 2013-September 2014).

\section{Disclosure statement}

No potential conflict of interest was reported by the authors. 


\section{Notes on contributor}

Lisa Perrott is Senior Lecturer at the University of Waikato. Her research traverses audiovisual media, music video, animation, cultural studies, audience and fan studies. Lisa is co-editor of the Bloomsbury book series: New Approaches to Sound, Music and Media. She is the author of 'Bowie the Cultural Alchemist: Performing Gender, Synthesizing Gesture and Liberating identity'(2017), published in Continuum: Journal of Media \& Cultural Studies, and is currently completing her monograph David Bowie: Music Video, Transmedia and Collaborative Process (Bloomsbury, forthcoming).

\section{ORCID}

Ana Cristina Mendes (D) http://orcid.org/0000-0002-3596-0701

Lisa Perrott (1) http://orcid.org/0000-0002-9788-9584

\section{References}

Anderson, B., 1991. Imagined communities: reflections on the origin and spread of nationalism. London: Verso.

Barker, M., 2003. Introduction. In: M. Barker and T. Austin, eds. Contemporary hollywood stardom. London: Arnold, 1-9.

Bolter, J.D. and Grusin, R., 2000. Remediation: understanding new media. Cambridge: MIT Press.

Buonanno, M., 2008. The age of television: experiences and theories. Bristol: Intellect.

Butler, J., 1990. Gender trouble: feminism and the subversion of identity. London: Routledge.

Cinque, T., Moore, C., and Redmond, S., eds, 2015. Enchanting David Bowie: Space/Time/Body/ Memory. New York: Bloomsbury.

Cinque, T. and Redmond, S., eds., 2014. The unearthly David Bowie. Celebrity studies, 4 (3). special issue.

Derfoufi, M., 2015. Embodying stardom, representing otherness: david Bowie in 'Merry Christmas Mr. Lawrence'. In: E. Devereux, A. Dillane, and M.J. Power, eds. David Bowie: critical perspectives. London: Routledge, 160-177.

Derrida, J., 1988. Signature event context. Limited Inc, 10, 1-25.

Derrida, J., 1994. Specters of Marx: the state of the debt, the work of mourning and the new international. trans. Peggy Kamuf. New York: Routledge.

Dyer, R., 1979. Stars. London: BFI.

Dyer, R., 1986. Heavenly bodies: film stars and society. London: Routledge.

Fisher, M., 2014. Ghosts of my life: writings on depression, hauntology and lost futures. Alresford: Zero Books.

Friesen, N., 2013. Wandering star: the image of the constellation in Benjamin, Giedion and McLuhan [online]. Available from: https://www.academia.edu/4032277/Wandering_Star_The_Image_of_ the_Constellation_in_Benjamin_Giedion_and_McLuhan [Accessed 31 May 2018].

Gledhill, C., ed, 1991. Stardom: industry of desire. London: Routledge.

Hansen, S. and Danny, F., 2015. 'This is not a Banksy!': street art as aesthetic protest. Continuum, 29 (6), 898-912.

Holmes, S. and Redmond, S., eds, 2006. Framing celebrity: new directions in celebrity culture. London: Routledge.

Jenkins, H., 2006. Convergence culture: where old and new media collide. New York: New York University Press.

Johnson, K., 2015. David Bowie is. In: E. Devereux, A. Dillane, and M.J. Power, eds. David Bowie: critical perspectives. London: Routledge, 1-18.

Kelleter, F., 2014. Serial agencies: the wire and its readers. Winchester: Zero Books. 
Latour, B., 1993. We have never been modern. Trans. Catherine Porter. Cambridge: Harvard University Press.

Marshall, P.D., 2014. Seriality and persona. M/C journal, 17 (3), 1-10.

McLuhan, M., 1951. The mechanical bride: folklore on the industrial man. New York: Vanguard Press. McLuhan, M., 1962. The Gutenberg galaxy: the making of typographic man. Toronto: University of Toronto Press.

McLuhan, M., 1964. Understanding media: the extensions of man. Cambridge: MIT Press, 7-23.

Nayar, P.K., 2009. Seeing stars: spectacle, society and celebrity culture. London: Sage.

Ndalianis, A. and Henry, C., 2002. Stars in our eyes: the star phenomenon in the contemporary era. Westport. Conn: Praeger.

Rojek, C., 2001. Celebrity. London: Reaktion Books.

Shneidman, E., 1973. Deaths of man. New York: Quadrangle.

Stevenson, N., 2006. David Bowie: fame, sound and vision. Cambridge: Polity.

Williams, B., 1993. Shame and necessity. Berkeley, CA: University of California Press. 